Recruitment of Records Management Practitioners in Jamaica's Public Sector and its Implications for Professional Practice

\begin{tabular}{|r|l|}
\hline Journal: & Records Management Journal \\
\hline Manuscript ID & RMJ-10-2016-0039.R3 \\
\hline Manuscript Type: & Research Article \\
\hline Keywords: & $\begin{array}{l}\text { Records management, Jamaica, Education, Recruitment, Public sector, } \\
\text { Training }\end{array}$ \\
\hline \multicolumn{2}{|l}{} \\
\hline
\end{tabular}

SCHOLARONE ${ }^{\text {Mx }}$

Manuscripts 


\title{
Recruitment of Records Management Practitioners in Jamaica's Public Sector and its Implications for Professional Practice
}

\begin{abstract}
Purpose (mandatory): This paper is part of a larger doctoral study completed at the University College London that investigated the connection between records management (RM) education and national development. The specific objectives of this paper are to highlight the recruitment practices in the RM profession in Jamaica's public sector and their implications for professional practice.

Design/methodology/approach (mandatory): The research is a qualitative mixed methods study, which mainly utilises data from 34 interviews done among RM practitioners and educators, and development administrators and analysts in Kingston and Spanish Town, Jamaica.

Findings (mandatory): The study found that there is an urgent need for a change in how RM practitioners are recruited for their roles in Jamaica's public sector. More coherent frameworks and a more coordinated effort are required to support for the recruitment of practitioners.

Research limitations/implications (if applicable): This research is specific to the Jamaican case, therefore, it provides little basis for generalisation. Consequently, the study seeks to make no claims that the results in the Jamaican context are generalisable to other societies. Nonetheless, the conclusions and recommendations may be instructive in other environments.

Social implications (if applicable): The study evaluated some of the existing practices for the recruitment of RM practitioners. As a result, the findings should enhance the knowledge about the human resources needs in RM in Jamaica.

Originality/value (mandatory): In addition to providing some directions for future research, the study also gives voice to a diverse group. It brings together an analysis of national discourses around RM recruitment practices. This is done through the multifaceted views of Jamaican RM practitioners, development administrators and RM educators represented in the interviews.
\end{abstract}

Keywords: Records Management, recruitment, education, training, public sector, Jamaica

Article Classification: Research Paper

\section{INTRODUCTION}

Records management (RM) staff, working as part of the wider public service team, plays a critical role in supporting government services and gaining the desired outcomes for public sector transformation and 
improvement. RM practitioners play an essential role in planning, implementing, and supporting RM systems and its users. Therefore, RM services require both adequate capacity (i.e. sufficient in numbers) and capability (i.e. sufficient in competency) among practitioners.

Both the amount of RM staff present within an organisation, and the capability of staff to perform their requisite tasks will affect the outcome of an organisation's work. Cook (1983) in addressing the training needs of archives and RM practitioners in the Caribbean noted that "...there is a wide and growing acceptance of the view that a supply of trained manpower...will materially improve the development of...the management of government records" (Cook, 1983, p. 19). Therefore, having the right people, with the right knowledge and skills to support RM services is critical. Thus, an investigation of the recruitment practices in RM may provide greater insight regarding the occupational culture in Jamaica's public sector. The specific objectives of this paper are to identify:

1. How RM practitioners are recruited in Jamaica's public sector;

2. Whether recruitment practices enable RM practitioners to fulfil their responsibilities; and

3. Make recommendations regarding the methods of preparing practitioners for their responsibilities.

\section{RESEARCH CONTEXT}

Since 1996 the Government of Jamaica (GoJ) through its Public Sector Modernisation Programme (PSMP) has sought to transform and improve the public service. In 2001, the GoJ, tabled in Parliament, Ministry Paper 56/2002, Government at Your Service, Public Sector Modernisation Vision and Strategy 2002-2012. This Ministry Paper was " to signal a more comprehensive coordinated approach to reform in the public sector focusing on long term goals rather than short term, multi-project activities" (http://www.cabinet.gov.jm/areas_responsibility/pstm). In that Paper, it was noted that by 2012 " $100 \%$ of 
public servants will work within organisations operated on the principles underlying executive agencies" (Cabinet Office, 2003, p.30). This means that senior managers would be required to "directly manage human resources in their organisations; set performance targets for every member of staff and assess them against these targets, and implement performance management and incentive schemes" (Cabinet Office, 2003, p.42). Thus, the aim was to have government entities modernised to become performance based institutions (PBIs), with a view to improve the quality of services.

By establishing PBIs, the government sought to bring together the various elements of the ongoing reform programme in the public sector. In essence, this initiative to transform and improve Jamaica's public sector intends to address public sector efficiency and ease of doing business (http://www.cabinet.gov.jm/). Administrators view both areas as critical in creating an enabling environment for growth and development in Jamaica.

Following the expiration of the Public Sector Modernisation Vision and Strategy 2002-2012, the GoJ in 2014 signed a five-year agreement with the Inter-American Development Bank (IDB) to fund the Public Sector Efficiency Programme (PSEP). This initiative, which builds on the previous programme, aimed at improving the efficiency of the public service. Its main objective is to strengthen capacity in human resource management, information and communication technology management, and control systems and accountability mechanisms. The administrators of the PSEP identified the following five areas of focus:

1. Business Facilitation and Customer Service - focusses on improving the quality of services that directly affect businesses;

2. Integrated Information and Communication Technology - aimed at improving the integration and 
harmonisation of government's information infrastructure and systems for enhancing service delivery;

3. Public Sector Human Resource Development and Management - concentrates on improving the capability of the public sector workforce to deliver government services;

4. Resource Management and Accountability - emphasises increasing transparency and accountability across Government;

5. Administrative Efficiency - aims at improving the utilisation of resources to deliver maximum output at minimum cost.

In order to support the modernisation and transformation initiative, the GoJ committed to improving the integration and harmonisation of government's information infrastructure and systems to enhance service delivery. However, administrators of the PSEP initiative recognised that to effectively undertake this mandate, they would need to implement an effective government-wide records and information management programme. This current initiative also highlights the need to strengthen the human resource capacity for RM in Jamaica's public sector to support service delivery in government business. However, for decades public sector entities have encountered significant challenges in RM practice, particularly as it relates to recruitment and staffing.

\section{Challenges in Records Management Practice}

In 1996, at the beginning of the PSMP initiative, a World Bank report emphasised that there were severe challenges in record management practice in Jamaica's public service. Some of the constraints found included: (a) chronic lack of record storage space that inhibited retrieval and preservation, (b) inadequate computerisation and record imaging equipment, (c) weak compliance units resulting in high incidents of unregistered businesses, and (d) unavailability of related information from other departments (World Bank, 
1996). The report highlighted that there were too few staff, inadequate training resources, weak recordskeeping capacity, low level of academically qualified staff, and a large contingent of temporary staff.

Consequently, World Bank highlighted that the challenges encountered in RM caused severe delays in government services and assisted in lowering the level of public sector performance. Both the government and the public authority responsible for RM, the Jamaica Archives and Records Department (JARD), recognised the impact of RM practice on efficient and effective service delivery. This impact on practice was particularly evident in the capability of RM staff to support service delivery.

\author{
Need for Improvement of Practitioners' Capability in Records Management Practice \\ The need to recruit qualified practitioners in RM in Jamaica has been identified since the 1960s. In the 1965 \\ Caribbean Archives Conference convened by the Government of Jamaica and University of the West Indies, \\ stakeholders noted that there were operational needs in RM which required practitioners who were \\ adequately prepared for their roles (Alexander-Gooding \& Black, 2005). Although much was not done then to \\ improve the situation, by the 1980s some thought was given to making provisions for qualifications in RM.
}

\begin{abstract}
In 1981, the International Council on Archives (ICA) on behalf of its Caribbean Regional Branch (CARBICA) requested the assistance of the United Nations Educational, Scientific, and Cultural Organisation (UNESCO) to undertake an evaluation of the extent and nature of professional preparation for archivists in the Caribbean region. In that evaluation, RM was considered a specialised area of the archival programme. The proposal was made to involve short and practical RM courses, with duration of one month (Cook, 1981). The courses targeted practitioners or others who intended to practice or supervise RM.
\end{abstract}


In 1982, Jamaica along with 14 other Caribbean countries, submitted an application to UNESCO to establish a regional facility for professional preparation in the field of archives and RM (Cook, 1983). In that submission they indicated, that due to significant growth in the discipline, it was imperative to give greater priority to the present and future capacity needs in archives and RM. Cook (1983) explained that in order to meet the immediate needs in the profession, they needed to review the current needs.

\section{Introduction of Records Management Education Programmes}

Seeing the need to focus on RM to support the preservation of archival records, the University Archivist at the University of the West Indies, Mona (UWI) in 1991, established an integrated archives and RM programme delivered as a special certificate programme offered over two summers. The summer programme was opened to records assistants to provide an introduction in RM. Creed-Nelson and Williams (1997) noted however, that the certificate programme was insufficient to prepare those being recruited to the RM profession:

This single certificate course barely 'scratches the surface' of our present training needs. What is required at the tertiary level, are ongoing diploma and degree courses especially for persons who hold responsibility for records and information management (p.12).

Practitioners such as Creed-Williams and Nelson believe that more opportunities are required in Jamaica to build the local capabilities for continuity in the profession at the higher level. Similarly, practitioner, Emerson Bryan noted the deficiencies in supporting RM practitioners in Jamaica, as none of the three main baccalaureate-granting institutions in Jamaica offered a degree programme in the discipline (Bryan, 2003). Bryan (2003) noted that RM courses offered were electives within programmes designed specifically for other fields. For those recruited to direct RM services, they usually require qualification in Library and Information Studies (LIS) at the undergraduate or postgraduate level. However, the LIS degree often completed at the 
Department of Library and Information Studies (DLIS), UWI, does not seem to meet the present needs among RM practitioners. Thus, there seem to be present challenges in undertaking RM functions in organisations, particularly with the changes occurring in the society.

\section{Changes Prompting the Need for Improve Capabilities among Practitioners}

Changes such as: (a) the passing of the ATI ACT; (b) the Government's strategy to establish RM units in all government departments in Jamaica; (c) the launch of Online Government initiatives across the Caribbean, which increased the demand for information specialists to work in a service-oriented economy; (d) rapid changes in both private and public institutions to shift from paper-based to automated solutions to undertake organisational activities, and (e) the need to support decision-making and accountability prompted the decision to include RM courses in the DLIS, UWI programmes (Compton-Smith, Duff \& McDonald, 2007). Nevertheless, the need to make provision for more in-depth programmes in RM is still a challenge in Jamaica. Although, there are various initiatives presently underway, which are likely to make RM a prioritised area in Jamaica to support national development, if practitioners are recruited without adequate preparation for their roles, then it is likely that development initiatives will be hindered.

The Government recognised the latter challenge. Thus, the GoJ had commissioned, from the mid-1990s, the Archives Advisory Committee (AAC) from JARD to evaluate the RM needs in government entities. The AAC directed public authorities to establish an effective RM programme. The Committee drafted a "Proposal for the creation of an Information Resources Division in each Government Department" (Agere, Lemieux \& Mazikana, 1999, p.113). The proposal, which was accepted by the government, highlighted the problems encountered in records and information management, drafted a model to address the challenges, and 
emphasised the need for an integrated career path for staffing in information-related fields (Agere, Lemieux \& Mazikana, 1999). Consequently, the Records and Information Management (RIM) staffing series was added to the already established public sector professional category, Public Information and Documentation Group (PIDG). The PIDG/RIM series, "covers work that is involved with the processing, transactions and management of records and documents in an organisation's information and records system" (Cabinet Office, Jamaica, 2002, p. 3). The need to improve the work of RM practitioners in MDAs became a significant thrust in the early 2000 s.

Helen Rumbolt, President, Access to Information Association of Administrators and Director, Documentation Information and Access Services (DDIAS) at the Ministry of Finance and the Public Service, noted that:

There was...a lot of distrust in the competence of the records officers to locate files on demand. Management of documented corporate activities was lacking or in most cases reduced to a clerical activity with no accountability of their stewardship (Rumbolt, 2006, p.75).

During the assessment of registries in preparation for the Freedom of Information legislation, later called the Access to Information Act, administrators found further challenges. These challenges included disorganised records centres, inaccessible records, chronic retention of records, and undocumented policies, guidelines and system changes. They also found a lack of qualified staffing and overall absence of an effective recordkeeping culture within government agencies (Rumbolt, 2006). The employment of unqualified individuals in RM positions also contributed to the hindrance to professional practice and weakened many RM related services in the Jamaican public sector. Thus, during the implementation of the ATI Act in 2004, the 16 ministries that existed were assigned a Records and Information Manager, since in 1996 only one Records Manager existed (Aarons, 2005). This approach significantly increased the number of RM practitioners in Jamaica's public sector. 
Capability strengthening, in the form of training, prepared the practitioners for their roles. Aylair Livingstone, Director, Access to Information Unit, noted that "Effective practices in RM were encouraged and implemented through collaborative training with the Government Archivist's office and a team of Records Analysts" (Livingstone, 2005, p. 6). Rumbolt (2006) added that public authorities identified training needs and training was "Conducted to equip staff with the requisite skills needed to administer the Act" (p.77). However, Rumbolt (2006) argued that the preparation of practitioners needed to be more in-depth:

A comprehensive programme for the training of records managers through scholarship, attachments, distance learning and otherwise should be undertaken through government to build and strengthen the cadre of professionals operating in this field and to ensure continued success of the operations of the Act (p. 80).

Thus, Rumbolt highlights that in order to have a successful RM programme in Jamaica's public sector there are two critical steps. First, practitioners must be well-prepared for their roles. Second, capable practitioners are required to ensure continued success in carrying out RM roles. These needs are likely to impact professional practice and how well the RM function is able to support service delivery in the public sector.

\section{LITERATURE REVIEW}

Government business commences with individuals interacting with a government process. The services provided through this process comprise tasks, which generate an information product, often in the form of paper or electronic records (McDonald, 2002). Records provide documented evidence of the activities undertaken within organisations. An activity is "An action or set of actions undertaken by an individual, a group of individuals or a corporate body, or by employees or agents acting on its behalf and resulting in a definable outcome" (Shepherd \& Yeo, 2003, p. 2). To serve the business aims, organisations need to capture, organise, and manage the records of these activities. 
However, often in developing countries, practitioners encounter significant difficulties in managing the records placed under their stewardship. It is difficult to find staff with the required competencies and capabilities to support RM activities. However, based on the literature, one of the reasons for this challenge is poor recruitment practices.

\section{Challenges with Records Management Practitioners Capabilities}

Finding the appropriate staff to support RM is a significant challenge for some developing countries such as Jamaica, Ghana and Kenya. Victoria Lemieux in 2001, in her study emphasised that the failure of Jamaican commercial banks to establish systems of internal accountability and control in the 1990s, obstructed the economic development initiative in Jamaica. Lemieux (2001) reported that effective records accountabilities and controls were crucial to the operation of accountability systems that provided the basis for internal control and sound decision-making in private sector entities. However, when accountability systems were weakened because of ineffective record keeping, management was unable to access the information needed to maintain operational control and make sound decisions which left businesses weak and vulnerable to collapse. One of the impediments to business viability and accountability which Lemieux found was the lack of required capabilities and special skills among practitioners to carry out RM functions in the Jamaican organisations studied.

Similarly, in developing countries in Africa, challenges exist with the recruitment of required practitioners for RM. Akotia (2003) argued that the absence of skilled personnel was a part of the systemic and structural weakness in Ghana's public sector. Later work by researchers Henry Kemoni and Patrick Ngulube, in 2008, analysed "The relationship between RM, public service delivery and the attainment of the United Nations 
Millennium Development Goals in Kenya". The study was conducted through an examination of published and unpublished works, a survey of $75 \%$ of the government ministries in Kenya and interviews with ministerial officers and personnel at the National Archives and Documentation service.

The researchers found that poor RM practice encouraged ad hoc decision-making, the inability of government to find precedents for decisions, wastage of limited resources, and powerlessness to prove fraud, because authorities were unable to complete meaningful audit trails. Since there was an inadequate infrastructure, including readily available, accessible and competent staff, for RM, the government was unable to support integrity and accountability in the public sector. The survey of the ministries showed that as a result of ineffective RM practice, service delivery in the Kenyan public sector was negatively affected and the achievement of the MDGs was hampered.

\section{Recruitment of Practitioners in the Public Sector}

Davidson, Lepeak and Newman (2007) in their study on recruitment and staffing in the public sector in the United States of America (USA) noted that recruiting and staffing are two of most critical activities within the human resources $(\mathrm{HR})$ domain. The process involves identifying and attracting the right people to fill positions, ranging from upper management and key decision-maker roles to entry-level personnel. However, finding the right person for each position may be a challenge for any organisation, but it is particularly difficult for public sector entities. Although these findings derive from the USA, a developed country, recruitment of staff in the public sector in the developing country seems to encounter similar challenges.

While recruitment of staff in the public sector on a whole may be a challenge, Harries (2008) pointed out that 
RM personnel are central to the delivery of outcomes in the modernisation process, which is occurring in government business. Therefore, he encouraged RM practitioners to position themselves to confront the new challenges, which he believed will require them to play an interventionist role, in which they move from the concept of accountability as answerability, to that of accountability as a responsibility. Thus, RM practitioners within public organisations are expected to be more responsible in undertaking their roles. Nonetheless, those persons recruited for RM roles are not always in the position to carry out those responsibilities.

This challenge with responsibility was quite evident in the case of Namibia's public service investigated by Nengomasha (2009). According to Nengomasha's findings, most of the RM staff interviewed in Namibia's public sector, had 'O' Level qualifications, completed at the end of secondary school. Only 15 per cent, three of the 20, records keeping staff interviewed had any formal education in RM. This 'low level' education among practitioners had negative consequences for the provision of effective RM services. Staff were sometimes illprepared to take up RM responsibilities, and oftentimes their roles were not taken seriously in organisations. Nengomasha therefore concluded that the lack of professional education among records personnel hindered the implementation of RM programmes.

A similar hindrance was found in Zimbabwe by Chaterera (2016), who examined the status quo in Zimbabwe's government ministries regarding the basic requirements in RM. According to Chaterera, public RM in Zimbabwe is given a very low priority due to the country's economic downturn and inadequate financial resources. As a result, RM personnel were not motivated to work as they are not treated as key resource persons. Consequently, RM practitioners there often found themselves at the periphery of their organisation's plans. This resulted in a prevalence of poor RM practice which in turn led to delays and even failure by 
members of the public to access government services. The overall result of the research revealed that public service delivery is therefore at risk due to inadequate RM practice in the public sector. Thus, it is imperative to assess the impact of recruitment practices in RM on public sector delivery.

\section{METHOD}

Although the larger doctoral study used three techniques (focus group, documentary evidence and semistructured interviews) to collect the data, this article draws mainly on the interview data. The semi-structured interviews were conducted among RM practitioners, educators, and development administrators and analysts. The semi-structured interviews were used as the primary technique for the data collection in the study. Thirtythree interviews were conducted, with 34 participants. The interviewees included 15 RM practitioners, 7 RM educators, 1 current RM student, 10 development administrators and analysts, and 1 representative of a large corporation without a RM programme.

To ensure that the interviewees represented a wide range of participants and perspectives, the researcher used a purposive sampling technique to select interviewees. Purposive sampling is applied in situations where the researcher is familiar with specific people or events (Denscombe, 2003). Individuals were deliberately selected because they were likely to provide rich data for the research.

Questions around the general topic of the role of RM education in Jamaica's development initiative were common in all the interviews. However, all categories (RM practitioners, educators and administrators and analysts) of interviewees were not asked the same questions. Interview guides were created for the three categories. 
Anonymity and ethical issues were not considered a major concern by the interviewees, but the normal ethical procedures were followed. Although many were willing to be named, the researcher decided to treat the identification of all interviewees consistently. All interviewees were pseudonymised and each assigned a number, for example, Interviewee 01.

\section{RESULTS AND DISCUSSION}

The 34 semi-structured interviews provided rich information for probing the issues. The interviewee data is presented through the use of verbatim quotes, to illustrate key findings. In an effort to understand and use the data collected, the researcher adopted the data analysis steps of organisation, perusal, classification and synthesis encouraged by Creswell (see Leedy \& Ormrod 2005, p. 151). Using this method assisted in determining the categories and patterns from the corpus of data, later grouped. Words and phrases were used to represent the topics and patterns as suggested by Creswell (1994, p. 155). These words and phrases operated as codes for the data, and the data that related to each code collated. In addition, the ATLAS.ti software for qualitative data analysis was used for manipulation and better management of the data.

\section{Recruitment and status of RM practitioners}

To provide the required support for public service delivery and achieve the desired outcome, the RM service must be prioritised, in that it must be furnished and equipped with the required resources, particularly staff. This research sought to collectively present the expectations regarding RM staffing in Jamaica's MDAs, which are required to support public sector delivery. The discussion in the section that follows focusses on the provision to support recruitment in RM in Jamaica's public service. The Civil Service Establishment (General) 
Order, which lists the established posts in the public service in Jamaica, was used to evaluate the number of RM practitioners in Jamaica's public service.

\section{Table 1. Number of Practitioners in the Five RM Series}

The data shown in Table 1 highlight that there are five Records Series in the public sector. However, the majority of practitioners in the Jamaican public sector are employed to the PIDG/RIM series. Consequently, the practitioners interviewed for this study were drawn mainly from the PIDG/RIM series. Nonetheless, the views of practitioners from the PIDG/AR and PIDG/HR series, as well as practitioners working in the private sector, were also included in the research, though to a limited extent. This approach helped to balance the views and provide an overall understanding of the RM culture, challenges and needs within the Jamaican setting.

\section{Table 2. RM Career Path for PIDG/RIM Series}

As shown in Table 2, the PIDG/RIM series supports a career path ranging from the junior level (Records Clerk) to the senior level (Records and Information Manager) positions in the profession. The Cabinet Office (2002) provides a description of these roles, which are briefly highlighted here. The first level of practitioner, the Records Clerk, is at the entry level of the profession. The Records Officer 1/Leave Clerk position is the first level of supervisory assignment in the clerical aspect of the work. The Records Officer 2, also commonly referred to as Senior Records Officer (SRO), is a mid-level practitioner. They are responsible for the operation of a segment of the operations of the unit. The Records Administrator's or Information Administrator's duties include the supervision of the information and dissemination centre of an 
agency. Finally, the Records and Information Manager (PIDG/RIM 5) carries the responsibility for all the administrative and professional functions of the library, registry and/or information unit.

Based on the latter structure, provision is made for the appointment of at least five practitioners to support the RM service in MDAs. These practitioners have specific roles and responsibilities required to support the RM function. Each practitioner should be prepared in some way to support their roles and responsibilities, guided by their requisite qualification and experience.

\section{Appointment of Practitioners at the Professional Level}

The research findings show that having the PIDG/RIM structure has helped to significantly increase the number of RM practitioners appointed to Jamaica's public sector over the last decade. Interviewee 11, an Educator, who has worked with RM practitioner in the public sector for many years remarked:

I think over the years they have been growing. There are far more records managers now than 10 years ago. I see a continual growth in this area (Interviewee 11, Educator).

These findings are broadly similar to those of Creed-Nelson and Williams (1997) and Aarons (2005). They noted an increase in the number of RM staff appointed to MDAs since the introduction of the PIDG/RIM series. However, even though the number of staff grew within RM departments, the findings also revealed that there were significantly less practitioners appointed at the higher level, suggesting a disparity in the appointment of staff at the lower and upper levels of the RM profession.

\section{Table 3. RM Practitioners in Jamaica's Public Service}

Table 3 shows that $90 \%$ of RM practitioners are employed at the entry level (levels 1 and 2 ). Those at mid- 
level (level 3) represent $9 \%$ of the practitioners. Only $1 \%$ of the staff is at the professional level (levels 4 and 5). Of the 11 practitioners listed at the professional level, only three are employed as Records and Information Managers or in an equivalent post. It is also important to note that the listed professional level practitioners were mainly concentrated in the Ministry of Finance and Planning, which has two practitioners employed at PIDG/RIM 4 and two at PIDG/RIM 5. According to a note in the Civil Service Order, two of the PIDG/RIM 5 positions "will be abolished when it becomes vacant" (Government of Jamaica, 2013, p. 50). Apart from the Ministry of Finance and Planning, only the Ministry of Agriculture and Fisheries had a practitioner at PIDG/RIM 5 (Government of Jamaica, 2013).

It is natural for fewer practitioners to be employed at the higher level of the profession. Nonetheless, these findings highlight a strange disparity between those appointed to the higher and lower levels of the RM profession in the public sector. Although only three practitioners are presently appointed at PIDG/RIM 5, the evidence from the data and literature suggest that the number of Records and Information Managers appointed to MDAs significantly increased over the last two decades. According to Creed-Nelson and Williams (1997), five ministries had appointed the equivalent of a Records and Information Resources Manager, in May 1997. John Aarons, Government Archivist, also observed similar appointments in 2005. According to Aarons (2005), the number of professional staff increased from one Records Manager at the Ministry of Finance in 1996, to 16 in all ministries that existed in 2005.

Based on the argument by Creed-Nelson and Williams (1997), and Aarons (2005), the evidence presented in Table 3 is now showing a strange decrease among professional level practitioners. This decrease is interesting, as JARD particularly recommended the appointment/placement of a Records and Information 
Resources Manager, or equivalent practitioner within each central public service entity. The appointment of this practitioner was deemed as critically important to the successful records and information management programme in MDAs. Creed-Nelson and Williams (1997) remarked that "This individual would be charged with the responsibility of spearheading the RM programme in government departments" (p. 6). Thus, it was expected that there would be an increase of RM staff at the professional level.

Decline of Staff at the Professional Level

Although it is evident that for a time the number of professional practitioners increased, something changed, which reduced the number over the last decade. Thus, the question is, why is there a decline of professional staff? The interview data shows that there are various contributing factors. Many of the interviewees suggest that the decline of professional level staff in the public service is as a result of the recruitment practices by government. According to the data, RM practitioners are mainly recruited at the entry level. As Interviewee 18, Educator, noted:

The organisation is not necessarily appointing people at the correct level... I don't think we are large enough to sustain the number of positions at an ideal level of say Records Manager. The openings are just not there. You still have the Director['s] position, but what they do is employ a Records Officer...

Since practitioners are "not appointed at the correct level", they generally lack the educational competence to perform their role and are also poorly remunerated. Interviewees also highlighted that the RM function is accorded a low status in many government entities. Therefore, interviewees serving as practitioners both in the public and private sectors, as well as RM educators concluded that on a whole, RM is not prioritised in the Jamaican public sector.

The decision makers are not sold on the concept of records being vital to decision making (Interviewee 06, Practitioner). 
Consequently, practitioners representing both the private and public sectors often used the term "low" to describe the state of Jamaica's public sector RM. For example, Interviewee 25A, practitioner, remarked:

Low status is attached to RM...because it is the deaf, the blind and the dumb that you assign or somebody who is giving trouble, so you send them to the records.

Apart from a low status being attached to RM within government entities, other interviewees remarked that government recruits at a "low" level:

Government recruits at a very low level and at an entry level, where these personnel are concerned (Interviewee 13, Practitioner).

Since RM is accorded "low" status within entities, and practitioners are often recruited at a "low" level, remuneration is also often "low". This is similar to Nengomasha (2009) finding. Her review of the management of public sector records in Namibia also highlighted that records practitioners are recruited at a low level, which is a risk to the national programme. According to Nengomasha, the shortage of skilled staff to manage records and the absence of formal training for RM professionals hindered the implementation of Namibia's RM programme.

This opinion shared by practitioners inside MDAs, and those observing the situation from the outside, implies that the actions of senior management in the Jamaica's public service seem to serve to devalue the RM function. Interviewee 32, Practitioner, explained:

I was annoyed at what I saw happening here...in terms of RM. It was just brushed aside. It was like one of those if it happens, it happens. There was really no priority for RM.

The prioritisation for the RM function was evident in how crucial activities and issues were handled. It is evident from the interview data shown, that how practitioners are recruited, the status they are accorded in their work environments, and the remuneration they receive for their services are significant challenges in 
securing the interest of RM professionals. This finding chimes with that of Chaterera (2016) who noted that RM practitioners often found themselves at the periphery of their organisation's plans.

The interview data also demonstrated that individuals may enter the RM service through unconventional circumstances. On one hand, practitioners, Interviewee $25 \mathrm{~A}$ and Interviewee 12 highlighted that administrators 'push', or 'transfer' individuals who are oftentimes incompetent, and lack the required knowledge and understanding to work in RM services. On the other hand, Educator, Interviewee 18 noted that MDAs do not appoint staff at the correct level, as the public sector is unable to sustain the ideal number of positions at the Records Manager level. In such cases, administrators will appoint someone as a director of the unit, and then employ Records Officers to support the RM function. Like Researchers Henry Kemoni and Patrick Ngulube (2008), the findings revealed that because of the low priority given to RM function, the department is sometimes used as a dumping ground for unproductive and indiscipline officers, which contributes to the poor state of RM in government entities.

Issues with Staff Qualification

These findings suggest that in general practitioners appointed to support and govern the RM service are not sufficiently qualified for these roles:

They are still a bit better off than before but you are not able to take your organisation where it needs to go. The organisation is not necessarily appointing people at the correct level so it is a chicken and egg situation (Interviewee 18, Educator).

Therefore, the tendency to recruit practitioners at a lower level might be a shortcoming for the profession in the public service, and a disadvantage to the organisations. Interviewees' responses seem to indicate that senior managers need to have a clearer understanding of the RM function, in order to appoint practitioners at 
the correct level:

I would like them to look at the job descriptions. The way central government does job description[s] now is more from an operational point of view, and my concern is about competencies. Government has a core set of competencies which broad brushes everybody, and sometimes they really do not relate to the job (Interviewee 13, Practitioner).

This suggests that although there are some guidelines, the public sector has not adequately planned for the RM service. This has been illustrated by interviewees who argued that since the public service is unable in all cases to employ a Records and Information Manager, they employ a Records Officer (i.e. a Records Officer 1 (PIDG/RIM 2), or the Records Officer 2 (PIDG/RIM 3)). As a mid-level practitioner, this officer is responsible for overseeing the operation of a segment of the unit, and supervising the work of the Records Clerk, and Records Officer 1. As shown in Table 3, 107, Records Officer 2s serve in the public service.

The job description and educational qualifications of the Records Officer 2 is dissimilar to that of the Records and Information Manager. They are expected to undertake different functions, and possess different capabilities. The Records Officer 2 is normally responsible for overseeing the operation of a section, while the Records and Information Manager carries the overall responsibility for all the unit's administrative and professional functions. Second, the Records Officer 2 should: be a high school graduate with 4 CXC/GCE O' Level subjects, complete training in Records and Information Management, and have 5 or more years' experience in the field. The Records and Information Manager should at the minimum, have completed a first degree, have five years' experience, and have completed training in RM.

Although the PIDG/RIM occupational group clearly outlines the responsibilities of RM practitioners, it seems administrators are willing to allow the Records Officer 2 to do the work of a Records and Information Manager. 
According to Bryan (2003), it may be that senior management is really not in touch with the various functions associated with the RM service. One interviewee remarked:

There is something with government. It gives us a higher profile yes, but you might be in a job in government now and that's what the requirements are and they are looking at the basic requirements that you need to function in a job like that (Interviewee 13, Practitioner).

In making the comment, 'a job like that', suggests an underlying perception that the qualification requirements of RM practitioners are taken as non-essential. This indicates that senior management have not appropriately identify practitioners for RM roles, and may believe that 'anyone' can fill the position, and so appoint at a lower level:

What you'll find in government organisations is that after the gardeners, artisans and the attendants, the next level up is what we use to call the clerical assistance but now they have changed to the records and information officers...Government recruit at a very low level and at an entry level (Interviewee 13, Practitioner).

The practice to recruit at a lower level within the public sector may be based on the old perception that RM is a clerical, rather than managerial function (Bryan, 2003). Educators interviewed in this study who have interacted closely with these practitioners in educational programmes are convinced that they are unable to sufficiently support the RM service in their organisations. Interviewee 13, a Practitioner, who also serves as an Educator, argued:

How are they going to solicit the backing of managers if they can't represent themselves?

The main point brought out by Interviewee 13 is that those practitioners, who are expected to manage the RM service, are unable to represent themselves. Rumbolt (2006) noted that within public organisations, staff in general distrusted the competence of Records Officers, who failed to act as good stewards of the records they were responsible for. In this study as well, there has been evident challenges with practitioners' ability to undertake their roles. As an illustration, Interviewee 14, Practitioner and Chair of one RM group, shared the 
following experience:

I went into their back room [and] I saw things thrown down all over the place. I asked the lady if those things were used. She said, "Yes, when I want something I just go into the box for it". So I said, suppose you have a fire? Do you have somebody that manages the records? She said, "No".

According to World Bank and IRMT (2000), the quality of any RM programme will be directly affected by the staff who operate it. Both among interviewees and in the literature, it has been indicated that practitioners are needed who understand the value of RM in an organisation, and who are able to follow and implement best practice in RM. As noted from the description of the Records and Information Manager's role, practitioners serving in this and similar roles are required to setup frameworks that enable consistency in practice and standardisation to ensure that the RM service achieves the required results. For this reason, Interviewee 18, Educator, was able to express the following:

There are still ministries and a number of the entities that are being managed by supervisors and registrars who are not fully trained. And even if they have done some training with us they are not at the level to fully appreciate the course work, so they struggle. And then on the job they are not able to transform their organisation.

Interviewee 18 noted here that an essential need within ministries and other entities is to ensure that practitioners have completed adequate training before being placed in a supervisory role in RM. Furthermore, as noted in the following quotation by Interviewee 23, Practitioner, exposure to knowledge in RM builds the confidence of practitioners:

Yes, it is extremely necessary because in that way the staff will see the things that they do on a daily basis, but they will not see it as just going through the motions.

Therefore, knowledge in RM helps to transform practitioners from being passive onlookers to active practitioners, working to transform their organisations. Knowledge of RM principles and practice is critical in helping practitioners to rationalise RM processes. They are able to understand why it is that they do what they 
do, and see their service as important to their organisations. This point was illustrated by Interviewee 10, Practitioner, who argued that education is necessary:

To teach people so they do not just fling things together. We see it coming in especially with the new staff, because they do not have an appreciation of the discipline.

It is important for practitioners to have sufficient knowledge and understanding that will help them to connect both practice and theory in RM (Webster, 1999). RM is not only a recognised profession but also a scholarly discipline (Webster, 1999). Naturally, practice and scholarship are expected to be complementary as demonstrated in the following quotation from Interviewee 22, Practitioner,

It is always good...to have the theoretical background...I think that it is crucial because unless you have the theory, you cannot necessarily appreciate the practical applications. You need to understand why, how, when, (and) what, in order to really apply that in the workplace.

Here, Interviewee 22 is highlighting a need for practitioners to gain an understanding of the theoretical background for RM, so that they may understand the practical work that they are currently undertaking. The method through which practitioners are prepared for their roles is critical in supporting both the immediate and long-term needs in the RM profession (IRMT, 2004; Katuu, 2009).

\section{Staff Commitment to Public Sector RM Roles}

Nonetheless, some practitioners felt that gaining additional education qualification in RM was a disadvantage to them:

You might be in a job in government now and that's what the requirements are...so acquiring additional education, it's an added plus to you and to your employee in terms of what they can get from you, but in terms of the job and what it requires this is what they will abide by. So, it's not gonna do much for you, they'll exploit you (Interviewee 13, Practitioner)

At present, educational parameters are in place for practitioners at the different levels of the PIDG/RIM. Once 
practitioners have reached the educational threshold, there seems to be no need to advance beyond the set requirement. As noted from the above quote by Interviewee 13, practitioners fear exploitation. In addition to the fear of exploitation, some practitioners have no intention of remaining in a RM position in government for the long term:

As it is now, persons just come in RM as a start-up. You get the feeling that they are not really interested. They say, "We don't find any interest in this thing, there is nothing in RM to hold us." (Interviewee 07, Practitioner).

Therefore, a significant theme that emerged from these comments is the ability of practitioners to sufficiently advance and feel fulfilled in their career. Popoola and Oluwole (2007), in their research on Career Commitment among RM Personnel in a State Civil Service in Nigeria, found a significant difference in the career commitment of RM personnel based on their level of education. They noted that higher levels of education provided the likelihood of better jobs and therefore enabled people to change jobs, while low educational qualifications may force personnel to have a stronger commitment to their present role. Thus, the more educated and experienced practitioners in RM are more likely to leave the public service for better opportunities elsewhere. In the current research, this is the result as RM practitioners are raising the issue that they are unable to meaningfully advance in their profession. Since practitioners are unable to advance in their profession, some felt that they should not over extend themselves and as a result lack commitment to their RM roles.

\section{Need to Improve the Educational Qualification of Practitioners}

Even though some practitioners had a fear of being exploited as they would not be compensated for their qualifications, majority argued that improving the educational qualification of practitioners would be beneficial in recruiting staff who are capable in undertaking RM roles. Interviewee 07, Practitioner, argued: 
In order for you to attract persons with a certain level of qualification, something has to be done where the posts are concerned, in terms of upgrading and all of that. As it is now, we won't be able to attract competent staff to work.

Interviewees are confident that once the bar is raised, practitioners will be required to be more competent and qualified.

Based on the views presented by interviewees, the employment of adequate and competent RM staff is crucial to any transformational process which is occurring in the public service. Interviewee 20, Development Administrator, when asked about the need to prepare RM practitioners for their roles commented that there is:

The need for us to have available to us, and for the state to make provision for even how it hires people, and who it hires for the routine collection of information. There is a lot being done, but I think there is a lot more to be done in this regard.

For interviewees, competent practitioners are needed to undertake RM duties, which are essential to the success of the service. This was evident in the approach taken to train personnel when various RM related initiatives were introduced in the public sector. Cook (1981) noted the importance of professional education to prepare practitioners to occupy positions commensurate with their qualifications and with the functions they are undertaking in their jobs.

Indeed, interviewees believed that it is only when practitioners are sufficiently prepared for their roles can they be effective in undertaking their duties. Take, for example, this quotation by Interviewee 07, Practitioner, describing the level of preparedness required among practitioners supporting RM services:

In order for our leaders and executive managers to make informed decisions, we need persons who are qualified and competent to manage our records... This information forms the corporate memory of the organisation, and therefore you need competent and qualified individuals to manage it properly.

RM practitioners have an essential role to play in supporting managers, which influences the delivery of public 
sector programmes (Cook, 1983; Kemoni \& Ngulube, 2008). Therefore, in order to gain the level of commitment required to support RM functions, adequate provisions to prepare and support RM practitioners in Jamaica are required. Creed-Nelson and Williams (1997) argued that the establishment of on-going diploma and degree courses in records and information management at UWI, and other tertiary institutions is critical especially for those persons who hold responsibility for records and information management. These authors also pointed out that there should be an expansion of training courses for registry staff. Since this proposal, others have highlighted similar requirements or steps that have been taken to meet some of the needs identified (Bryan, 2003; Compton-Smith, Duff \& McDonald, 2007). In that case, it is necessary to evaluate the current provisions available in Jamaica to prepare and support practitioners in RM roles so that it correctly administer responsibilities and meet the needs required for staffing capacity at the professional level:

As with other professions, from the initial stage of recruitment, you should have certain things set down, certain guidelines. If you are going to be employing a Records Officer, this person must meet the minimum qualification bar along with having some formal training in RM. I think that could be one of the first moves (Interviewee 07, Practitioner).

It is indicated here, that currently the public sector is deficient in workforce planning which has resulted in the employment of individuals with limited knowledge, skills and experiences. Interviewees are suggesting that effective workforce planning systems be established to determine the immediate staffing needs, and help to ensure that sufficient numbers of RM practitioners are prepared to meet the demands of the RM service. In this study, as with others (Kemoni \& Ngulube, 2008; Nengomasha, 2009), the underlying issue in appointing appropriate staffing for RM is connected to the organisational culture and estimated value placed on the function in organisations. 


\section{CONCLUSIONS AND RECOMMENDATIONS}

The findings suggest that in general practitioners appointed to support and govern the RM service are not sufficiently qualified for these roles as they lack the appropriate skillsets and personality traits for the RM occupation. Commonly this challenge exists because of the perception of senior management regarding the records management full and the expectations of those who are assigned RM responsibilities. However, the perception and expectation that public entities have of the RM programme, and the resulting resources provided to support the function will determine whether programme will sufficiently support the thrust for transformation and improvement of service.

The delivery of quality service in records management requires effective workforce planning. Senior management must take an interest in the records management service and its personnel by establishing standards for the profession. Effective workforce planning systems should be established to determine both the immediate staffing needs and help to ensure that sufficient numbers of records management practitioners are prepared to meet present and future demands. The decisions for RM staff recruitment must be based on an understanding of the factors that influence the needs and demands for a records management service in the Jamaican public sector. During planning, the number of staff (capacity) required for the department at the appropriate levels must be considered. The tasks that practitioners are required to perform must also be judged based on their abilities and understanding (capabilities). 


\section{References:}

Aarons, J.A., 2005. The Archives and Access to Information Act in Jamaica. Access to Information, 5 (Winter Edition). Available at: http://www.cartercenter.org/resources/pdfs/peace/americas/jamaica_enewsletter_vol5_winter.pdf [Accessed November 3, 2010].

Agere, S., Mazikana, P.C. \& Lemieux, V.L., 1999. Better information practices: Improving records and information management in the public service, London: Commonwealth Secretariat.

Akotia, P., 2003. Public sector records systems in Ghana: Some lessons in development management. African Journal of Library, Archives and Information Science, 13(2), 107-117.

Alexander-Gooding, S., \& Black, S., 2005. A national response to ISO 15489: A case study of the Jamaican experience. The Information Management Journal, (March/April), 62-66.

Bryan, E., 2003. The Records and Info Management Profession - View From Within the Jamaica Public Service. ACARM Newsletter, pp.10-17.

Cabinet Office, Jamaica., 2002. Government of Jamaica: Public Information and Documentation Group Records and Information Management. Kingston, Jamaica: Cabinet Office.

Cabinet Office, Jamaica, 2003. Government at your service: Public Sector Modernisation Vision and Strategy 2002-2012, Kingston, Jamaica. Available at: http://unpan1.un.org/intradoc/groups/public/documents/caricad/unpan012825.pdf [Accessed February 1, 2011].

Chaterera, F., 2016. Managing public records in Zimbabwe: the road to good governance, accountability, transparency and effective service delivery. Journal of the South African Society of Archivists, 49. Available at: http://www.ajol.info/index.php/jsasa/article/view/138461 [Accessed February 3, 2016].

Compton-Smith, C., Duff, W. M., \& McDonald, J., 2007. Blended e-learning techniques: Lessons learned from the delivery of distance learning courses to the University of the West Indies, Mona, Jamaica. In C. Peltier-Davis \& S. Renwick (Eds.), Caribbean libraries in the 21st century: Changes, challenges, and choices (pp. 303-314). New Jersey: Information Today, Inc.

Cook, M., 1981. Professional training needs for archivists in the Caribbean Region (No. FMR/PGI/TSU/81/197) (p. 28). Paris: United Nations Educational, Scientific and Cultural Organization (UNESCO). Available at http://unesdoc.unesco.org/images/0004/000472/047234eo.pdf. [Accessed March 9, 2013].

Cook, M., 1983. Caribbean Region: Training in archives and records management. United Nations Educational, Scientific and Cultural Organisation (UNESCO). Available at: http://unesdoc.unesco.org/images/0005/000569/056994eo.pdf [Accessed January 1, 2011].

Creed-Nelson, M. \& Williams, E., 1997. Records and information management in the public sector: An 
overview. Kingston, Jamaica: Conference Centre.

Creswell, J.W., 1994. Research design: qualitative \& quantitative approaches, Thousand Oaks, Calif: Sage Publications.

Davidson,G., Lepeak, S. \& Newman, E., 2007. Recruiting and Staffing in the Public Sector: Results from the IPMA-HR Research Series. Available http://unpan1.un.org/intradoc/groups/public/documents/ipma-hr/unpan027173.pdf [Accessed February 07, 2017].

Denscombe, M., 2003. The good research guide: for small-scale social research projects (2nd ed.). Maidenhead, Berkshire, England ; New York: Open University Press.

Government of Jamaica, 2013. The Civil Service Establishment Act: Proclamations, rules and regulations. The Jamaica Gazette Supplement, CXXXV1 (126), 1-670. Available at: http://www.mof.gov.jm/documents/documents-publications/document-centre/file/385-civil-serviceestablishment-g-order-2013.html

Harries, S., 2008. Managing records, making knowledge and good governance. Records Management Journal, 19(1), 16-25. doi:10.1108/09565690910937218

IRMT., 2004. Evidence-based governance in the electronic age: Final report (No. EBG/DGF/27). World Bank Development Facility.

Katuu, S., 2009. Archives and records management education and training: What can Africa learn from Europe and North America? Information Development, 25(2), 133-145. doi:10.1177/0266666909104714

Kemoni, H. \& Ngulube, P., 2008. Relationship between RM, public service delivery and the attainment of the United Nations Millennium Development Goals in Kenya. Information Development, 24(4), pp.296-306.

Leedy, P.D. \& Ormrod, J.E., 2005. Practical research: Planning and design 8th ed., Upper Saddle River, N.J.: Pearson Prentice Hall.

Lemieux, V., 2001. Competitive viability, accountability and recordkeeping: A theoretical and empirical exploration using a case study of Jamaican commercial bank failures. University College London, United Kingdom. Available at: http://discovery.ucl.ac.uk/1317703/1/272289.pdf. [Accessed March 6, 2012].

Livingstone, A., 2005. The Implementation of the Access to Information Act: The Jamaican experience, challenges and success. In National Workshop organised by Commonwealth Human Rights Initiative. New Delhi, India. Available at: http://www.humanrightsinitiative.org/programs/ai/rti/implementation/general/implementation_of_ai_act _jamaican_experience.pdf. [Accessed March 3, 2012]. 
McDonald, J., 2002. The Financial Capability Model and the records management function: An assessment. Available at: http://www.ppforum.cal. [Accessed April 6, 2012].

Nengomasha, C. T., 2009. Managing Public Sector Records in Namibia: a proposed model. Information Development, 25(2), 112-126.

Popoola, S. O., \& Oluwole, D. A., 2007. Career commitment among records management personnel in a State Civil Service in Nigeria. Records Management Journal, 17(2), 107-116. doi:10.1108/09565690710757904

Rumbolt, H., 2006. Challenges and successes in implementing the Access to Information Act in Jamaica. In The Carter Center, ed. Access to Information: Building a culture of transparency. Atlanta, GA: The Carter Center, pp. 73-80. Available at: http://www.cartercenter.org/documents/2364.pdf.

Shepherd, E. \& Yeo, G., 2003. Managing records : A handbook of principles and practice, London: Facet Pub.

Webster, B. M., 1999. RM: From professional to scholarly discipline. Information Management Journal, 20-30.

World Bank, 1996. Staff appraisal report: Jamaica Public Sector Modernization Project, Public Sector Modernization and Private Sector Division Country Department III Latin America and the Caribbean Region. Available at: http://wwwwds.worldbank.org/external/default/WDSContentServer/WDSP/IB/1996/07/29/000009265_396121 4122821/Rendered/PDF/multiOpage.pdf.

World Bank \& IRMT, 2000. Managing records as the basis for effective service delivery and public accountability in development: An introduction to core principles for staff of the World Bank and its partners. 


\section{Recruitment of Records Management Practitioners in Jamaica's Public Sector and its Implications for Professional Practice}

Table 1. Number of Practitioners in the Five RM Series

\begin{tabular}{lc}
\hline Series & No. of Practitioners \\
\hline Archives and RM(PIDG/AR) & 31 \\
Health Records (PIDG/HR) & 108 \\
Health Records Administrators (HRC/HR) & 3 \\
Health Records Clerks/Technicians (HTAC/HRT) & 0 \\
Records and Information Management (PIDG/RIM) & 1211 \\
\hline Total & 1353 \\
\hline
\end{tabular}

Source: Government of Jamaica (2013)

Table 2. RM Career Path for PIDG/RIM Series

\begin{tabular}{ll}
\hline Levels & Main Titles \\
\hline PIDG/RIM 1 & Records Clerk \\
PIDG/RIM 2 & Records Officer 1/Leave Clerk \\
PIDG/RIM 3 & Records Officer 2/Senior Records Officer \\
PIDG/RIM 4 & Records Administrator/ Information Administrator \\
PIDG/RIM 5 & Records and Information Manager \\
\hline
\end{tabular}

Source: Cabinet Office, Jamaica (2002, pp.6-17) 
Table 3. RM Practitioners in Jamaica's Public Service

\begin{tabular}{|c|c|c|}
\hline Levels & Main Titles & No. of Practitioners \\
\hline PIDG/RIM 1 & Records Clerk & 443 \\
\hline PIDG/RIM 2 & $\begin{array}{l}\text { Records Officer } 1 / \\
\text { Leave Clerk }\end{array}$ & 650 \\
\hline PIDG/RIM 3 & $\begin{array}{l}\text { Records Officer 2/ } \\
\text { Senior Records Officer }\end{array}$ & 107 \\
\hline PIDG/RIM 4 & $\begin{array}{l}\text { Records Administrator/ } \\
\text { Information Administrator }\end{array}$ & 8 \\
\hline PIDG/RIM 5 & $\begin{array}{l}\text { Records and Information } \\
\text { Manager }\end{array}$ & 3 \\
\hline Total & & 1211 \\
\hline
\end{tabular}

Source: Government of Jamaica (2013) 